\title{
Recombinant Human Chorionic Gonadotropin
}

National Cancer Institute

\section{Source}

National Cancer Institute. Recombinant Human Chorionic Gonadotropin. NCI Thesaurus. Code C528.

A recombinant therapeutic agent which is chemically identical to or similar to the endogenous glycoprotein hormone human chorionic gonadotropin (HCG). HCG binds to cells of the corpus luteum, thereby stimulating progesterone production and helping to maintain a secretory endometrium. ( $\mathrm{NCl04)}$ 